\title{
INFLUENCE OF CIGARETTE SMOKING DURATION ON ENDOTHELIAL CELL FUNCTION
}

\author{
Tatyana M. Popoval, Tatyana V. Gorbach'1, Tatyana I. Tsygankova ${ }^{2}$, Natalia O. Shushliapinal \\ ${ }^{1}$ Department of Biochemistry, Kharkiv National Medical University, Kharkiv, Ukraine \\ ${ }^{2}$ Outpatient Department of Kharkiv City Student Hospital, Kharkiv, Ukraine
}

\section{UTICAJ DUŽINE PUŠENJA CIGARETA NA FUNKCIJU ENDOTELIJALNIH ĆELIJA}

\author{
Tatyana M. Popoval, Tatyana V. Gorbach ${ }^{1}$, Tatyana I. Tsygankova ${ }^{2}$, Natalia O. Shushliapinal \\ ${ }^{1}$ Katedra za biohemiju, Harkov nacionalni medicinski univerzitet, Harkov, Ukrajina \\ 2 Ambulanta Harkov Gradske studentske bolnice, Harkov, Ukrajina
}

\begin{abstract}
Objective. Cigarette smoking represents an important factor for development of cardiovascular diseases. Both the amount and duration of cigarette consumption are in direct correlation to the increase in cardiovascular pathology. The aim of our research was to evaluate the influence of the cigarette smoking duration on the nitrate, nitrite, $S$ nitrosothiols and endothelin-1 levels in saliva of smokers.

Methods. For the purpose of this study, a total number of 60 subjects were recruited. They were divided into 4 groups based on the duration of cigarette consumption - non smokers - control $(n=15)$; group I $(n=15)$ - consumption of cigarettes for 2 years; group II $(n=15)-4$ years and group III $(n=15)-$ 6 years. The blood pressure, weight and height of all subjects were measured. Body mass index was calculated. Determination of nitrate, nitrite, S-nitrosothiols and endothelin-1 was done in each salivary sample collected from 60 subjects.

Results. Both systolic and diastolic blood pressure did not differ between the control group and group I. These parameters were significantly greater in group II and group III subjects compared to controls. Smokers of all groups and nonsmokers had normal body mass index values. The levels of salivary nitrate, nitrite and S-nitrosothiols were significantly lower in group II and group III compared to control group. Salivary endothelin-1 concentrations were significantly higher in subjects of group II and group III than controls.

Conclusion. In this study the substantial differences between smokers and non-smokers in levels of stable metabolites of NO and endothelin-1 are due to the causal effects of smoking.
\end{abstract}

Key words: cigarette smoking; saliva; nitrates; nitrites; $S$ nitrosothiols; endothelin-1; endothelium.

\section{INTRODUCTION}

Smoking is associated with a lot of adverse effects on health. Tobacco smoke contains approximately 4000 toxic chemicals including heavy metals, surfactants, cyanide, and fifty carcinogens, for example the nitrosamine compounds, nitrosonornicotine and 4-(methylnitrosamino)-1-(3pyridyl)-1-butanone $(1,2)$. Despite well-documented adverse effects, cigarettes remain one of the most popular

\section{SAŽETAK}

Cilj. Pušenje cigareta predstavlja važan faktor za razvoj kardiovaskularnih bolesti. Količina $i$ dužina upotrebe cigareta $u$ direktnoj su korelaciji sa povećanjem kardiovaskularne patologije. Cilj našeg istraživanja bio je da se utvrdi uticaj dužine pušenja na nitrat, nitrit, S-nitrosotiol $i$ nivo endothelin-1 u pljuvački pušača.

Metode. Za potrebe ove studije angažovano je ukupno 60 ispitanika, koji su podeljeni u četiri grupe na osnovu dužine korišćenja cigareta: nepušači - kontrolna grupa $(n=15)$; grupa I $(n=15)$ - koriste cigarete dve godine; grupa II $(n=$ 15) - četiri godine i grupa III $(n=15)$ - šest godina. Izmereni su krvni pritisak, težina i visina svih ispitanika. Izračunat je indeks telesne mase. Određivanje nitrata, nitrita, S-nitrosotiola i endotelina-1 obavljeno je na svakom uzorku pljuvačke sakupljene od 60 ispitanika.

Rezultati. Ni sistolni ni dijastolni krvni pritisak nisu se razlikovali između kontrolne grupe i grupe I. Ovi parametri su bili znatno veci kod grupa II i III u poređenju s kontrolnom grupom. Pušači svih grupa i nepušači imali su normalne vrednosti indeksa telesne mase. Nivoi salivarnih nitrata, nitrita $i$ S-nitrosotiola znatno su niži u grupama II $i$ III $u$ poređenju s kontrolnom grupom. Koncentracije salivarnog endotelina-1 bile su znatno veće kod ispitanika II i III grupe nego kod kontrolne grupe.

Zaključak. U ovoj studiji znatne razlike između pušača $i$ nepušača u nivoima stabilnih metabolita NO i endotelina-1 posledica su uzročnih efekata pušenja.

Ključne reči: pušenje cigareta; pljuvačka; nitrati; nitriti; S-nitrosotioli; endotelin-1; endotel.

legal consumer products used by young men and women. In $2017,23.0 \%$ (8.2 million) of all adults in Ukraine reported current tobacco use (self-reported current use of tobacco products on a daily or less than daily basis) in any form (40.1\% of males and $8.9 \%$ of females). Among everdaily tobacco smokers aged 18-34 years, smoking was initiated on average at 16.8 years of age, and $60.4 \%$ of tobacco smokers started smoking before age 18. The average number of cigarettes smoked per day was 17.1 among daily cigarette smokers (18.2 for males and 12.6 for females) (3). 
There are numerous data have documented a relationship between smoking and cardiovascular diseases (CVD) $(1,4,5)$. The majority of individuals who smoke cigarettes chronically will eventually succumb to CVD. However, despite major cardiovascular health consequences related to cigarette smoking, mechanisms of their influence on cardiovascular cell function are still being explored. The smoking of cigarettes increases the progression of atherosclerosis by an adverse effect on endothelial and smooth muscle cell functions as well as thrombotic disturbances (6-8).

The vascular endothelium plays a fundamental role in the regulation of vascular tone, thrombotic balance, growth and inflammatory responses (9). Dysfunction of these endothelium-dependent regulatory systems plays important role in the development of CVD that include hypertension and atherosclerosis. $(10,11)$. Among the risk factors for atherosclerosis, cigarette smoking correlates in the development of $\operatorname{CVD}(7,11,12)$. Although the precise mechanisms by which smoking could affect endothelial function are not clear, it is known cigarette smoking lead to the development of oxidative stress. During oxidative stress, the excessive generation of vascular superoxide anion and reactive oxygen species (ROS) are appeared. ROS play key role in the pathogenesis of CVD via lipid peroxidation, peroxynitrite mediated cell-damage, oxidation of low-density lipoprotein in vascular bed, activation of regulatory protein and intracellular cell transduction have been highlighted $(13,14)$.

Scientific evidence have been presented that tobaccorelated impairment of endothelial function may be related to its adverse effects on endothelial nitric oxide (NO) synthase $(15,16)$. Additionally, studies report that smoke interferes with L-arginine and $\mathrm{NO}$ metabolism, resulting in reduced NO formation (17). Several studies have reported that the reduced NO levels may be important in smoking-induced leukocyte-endothelial interactions, at least during the early stages.

$\mathrm{NO}$, nitrite $\left(\mathrm{NO}_{2}-\right)$ and nitrate $\left(\mathrm{NO}_{3}-\right)$ have gained supremacy as the available biomarkers of endothelial function. Nonetheless, no studies have been published about determination of the nitric oxide stable metabolites in combination with endothelin-1 in smokers.

Nitrites, nitrates and S-nitrosothiols have being measured traditionally in blood, urine and saliva. Saliva analysis is more acceptable noninvasive technique.

The aim of our research was to evaluate the influence of the cigarette smoking duration on the nitrate, nitrite, Snitrosothiols and endothelin-1 levels in saliva of smokers.

\section{PATIENTS AND METHODS}

\section{Subject characteristics}

This research study was conducted at the Outpatient Department of Kharkiv City Student Hospital and at the
Department of Biochemistry of Kharkiv National Medical University, Kharkiv, Ukraine, between January 2017 and November 2017. The study population was consisted of 60 subjects: 45 regular smokers and 15 non-smokers. Smoking behavior and lifestyle (physical activity and alcohol consumption) were recorded via a self-completed questionnaire. The information collected included: smoking status, duration of smoking (in years) and number of cigarettes smoked (per day). All subjects were assured that the results were confidential, in order to encourage accurate reporting of smoking habits. Smokers have smoked 8 - 20 cigarettes per day with tar yield $9-12 \mathrm{mg}$ and $0.8-1.2 \mathrm{mg}$ nicotine typical for the Ukrainian market.

The subjects were healthy young men with normal physical examination and used no medication or supplementation. Mean age of the 60 subjects was $20.9 \pm$ 0.1 years (median 21; range 19 - 22 years).

Four groups of 60 subjects were recruited: healthy non-smoking subjects (control group, $\mathrm{n}=15$ ); smoking healthy subjects have smoked for two years (group I, $\mathrm{n}=15$ ); smoking healthy subjects have smoked for four years (group II, $\mathrm{n}=15$ ); and smoking healthy subjects have smoked for six years (group III, $\mathrm{n}=15$ ).

All individuals were placed on a nitrate-restricted diet ( $<15 \mathrm{mg}$ per day) for 3 days before the study.

\section{Blood pressure measurements}

Between 8 and $10 \mathrm{AM}$, subjects were admitted in a warm $\left(20^{\circ}\right.$ to $\left.22^{\circ} \mathrm{C}\right)$ and quiet room. Blood pressure (BP) was measured using a standard cuff mercury sphygmomanometer on the left arm in a sitting position, after 10 - 15 min rest. All subjects underwent three BP measurements at either 1-min intervals. The average of the last two of three consecutive measurements was considered as the baseline BP.

\section{Physical measurements}

Body mass index (BMI) was calculated using the standard metric BMI formula $\left(\mathrm{kg} / \mathrm{m}^{2}\right)$. Based on the results of calculated BMI, normal group ranged from 18.524.9; overweight from 25-29.9 and obese higher/equal 30.

\section{Bioethics}

The study was conducted in compliance with the Declaration of Helsinki and in accordance with the local Ethical Committee. All participants gave their written consent to participate in the study.

\section{Collection of saliva samples}

An hour prior to saliva collection, subjects were instructed to avoid eating, drinking, smoking or oral 
stimulation to avoid the effect on salivary flow rate. Subjects were told to rinse their mouth with distilled water in order to remove debris and moisturize. Saliva collection was performed after 10 minutes of rest. The subjects were asked to sit in a relaxed and upright position, and saliva was allowed to drain into a test tube by gentle spitting. Saliva was collected during $15 \mathrm{~min}$ from 8 to 9 a.m. The five milliliters of unstimulated salivary samples were put on ice in precooled polypropylene tubes. All samples were then centrifuged at $3,000 \mathrm{~g}$ for 10 minutes at $40^{\circ} \mathrm{C}$ in order to remove debris. The supernatant (upper 2/3) of each sample was fractionated into $100 \mu \mathrm{l}$ aliquots and frozen at $-60^{\circ} \mathrm{C}$ until analyses (18).

\section{Salivary nitrates, nitrites, $S$-nitrosothiols and endothelin-1 measurement}

\subsection{Determination of nitrate and nitrite levels in saliva}

Nitrite $\left(\mathrm{NO}_{2}-\right)$ and nitrate $\left(\mathrm{NO}_{3}-\right)$ levels in saliva were determined by the method described by Miranda KM et al. (19). The sum of $\left(\mathrm{NO}_{2}-\right)$ and $\left(\mathrm{NO}_{3}-\right)$ was measured after the reduction of $\left(\mathrm{NO}_{3}-\right)$ to $\left(\mathrm{NO}_{2}-\right)$ by vanadium (III) combined with detection by the acidic Griess reaction. The $\left(\mathrm{NO}_{3}-\right)$ concentration was calculated by subtracting the $\left(\mathrm{NO}_{2}-\right)$ level from the total sum level.

\subsection{Measurement of salivary $S$-nitrosothiols}

The salivary S-nitrosothiols were measured spectrophotometrically. The principal of this method is based on formation of nitrite that are formed with $\mathrm{Hg}$ decay of S-nitrosothiols. Nitrites are detected using photometric strategy utilizing Griess reagent. This involves nitrite dependent diazotization of sulfanilamide, under strongly acidic conditions, followed by coupling a naphthyl ring to produce a chromophore.

\subsection{Determination of endothelin-1 level in saliva}

The salivary endothelin-1 level was measured using enzyme-linked immunosorbent assay kit (USA) according to the manufacturer's instructions. The optical density for each sample was measured at $450 \mathrm{~nm}$ using micro-ELISA plate reader (Ceres UV $900 \mathrm{C}$, BioTek Instruments Inc., Winooski, VT, USA). The endothelin-1 concentration in each saliva sample was calculated based on the standard curve.

\section{Statistics}

Statistical analysis of the data was carried out using the STATISTICA program (StatSoftInc., USA, version 7.0). The results were expressed as mean and standard error of mean (SEM). Differences in mean values between groups were analyzed with the Mann-Whitney U test (MW U test) for comparison of 2 groups and the Kruskal-Wallis test (KW) for comparison of 4 groups. The significance level was set at $\mathrm{p}<0.05$.

\section{RESULTS}

Clinical characteristics of each group are shown in Table 1. Age was well matched across all groups, taking into account the different minimum age for smoker groups and control group. The significant increase in cigarette

Table 1. Clinical characteristics of the groups in whole study population

\begin{tabular}{|c|c|c|c|c|c|}
\hline $\begin{array}{l}\text { Variables all groups } \\
(\mathrm{n}=60)\end{array}$ & $\begin{array}{l}\text { Control group } \\
(\mathrm{n}=15)\end{array}$ & $\begin{array}{l}\text { Group I } \\
(n=15)\end{array}$ & Group II $(n=15)$ & $\begin{array}{c}\text { Group III } \\
(\mathrm{n}=15)\end{array}$ & KW \\
\hline Gender (male), $\mathrm{n}$ & $\mathrm{n}=15$ & $\mathrm{n}=15$ & $\mathrm{n}=15$ & $\mathrm{n}=15$ & \\
\hline Race (white), $\mathrm{n}$ & $\mathrm{n}=15$ & $n=15$ & $\mathrm{n}=15$ & $\mathrm{n}=15$ & \\
\hline Age (years) & $20.93 \pm 0.25$ & $20.73 \pm 0.18$ & $21.07 \pm 0.23$ & $21.40 \pm 0.16$ & $\begin{array}{c}\mathrm{NS} \\
\mathrm{H}=5.3, \\
\mathrm{p}=0.1499\end{array}$ \\
\hline $\begin{array}{l}\text { Duration of daily smoking } \\
\text { (years) }\end{array}$ & 0 & $2.39 \pm 0.06$ & $4.53 \pm 0.07$ & $6.33 \pm 0.09$ & $\begin{array}{l}\mathrm{H}=39.45 \\
\mathrm{p}=0.0000\end{array}$ \\
\hline $\begin{array}{l}\text { Daily cigarette } \\
\text { consumption } \\
\text { (cigarettes/day) }\end{array}$ & 0 & $11.20 \pm 0.45$ & $14.6 \pm 0.5$ & $17.07 \pm 0.69$ & $\begin{array}{l}\mathrm{H}=26.71 \\
\mathrm{p}=0.0000\end{array}$ \\
\hline BMI $\left(\mathrm{kg} / \mathrm{cm}^{2}\right)$ & $22.49 \pm 0.28$ & $22.53 \pm 0.17$ & $22.47 \pm 0.18$ & $22.81 \pm 0.17$ & $\begin{array}{c}\mathrm{NS} \\
\mathrm{H}=2.12 \\
\mathrm{p}=0.5484\end{array}$ \\
\hline $\begin{array}{l}\text { Systolic blood pressure } \\
(\mathrm{mm} \mathrm{Hg})\end{array}$ & $123.33 \pm 0.98$ & $125.27 \pm 0.85$ & $132.20 \pm 0.59$ & $132.87 \pm 0.53$ & $\begin{array}{l}\mathrm{H}=41.71 \\
=0.0001\end{array}$ \\
\hline $\begin{array}{l}\text { Diastolic blood pressure } \\
(\mathrm{mm} \mathrm{Hg})\end{array}$ & $78.13 \pm 0.95$ & $80.07 \pm 0.73$ & $80.73 \pm 0.56$ & $81.40 \pm 0.62$ & $\begin{array}{c}\mathrm{H}=8.22 \\
\mathrm{p}=0.0418\end{array}$ \\
\hline
\end{tabular}

Notes: Values are given as mean \pm SEM; $p$ values are for comparing multiple independent groups (Kruskal-Wallis test); NS, nonsignificant. 
consumption was found in group II and group III. Group III smoked significantly more cigarettes compared to group II and group I. Duration of smoking had a positive

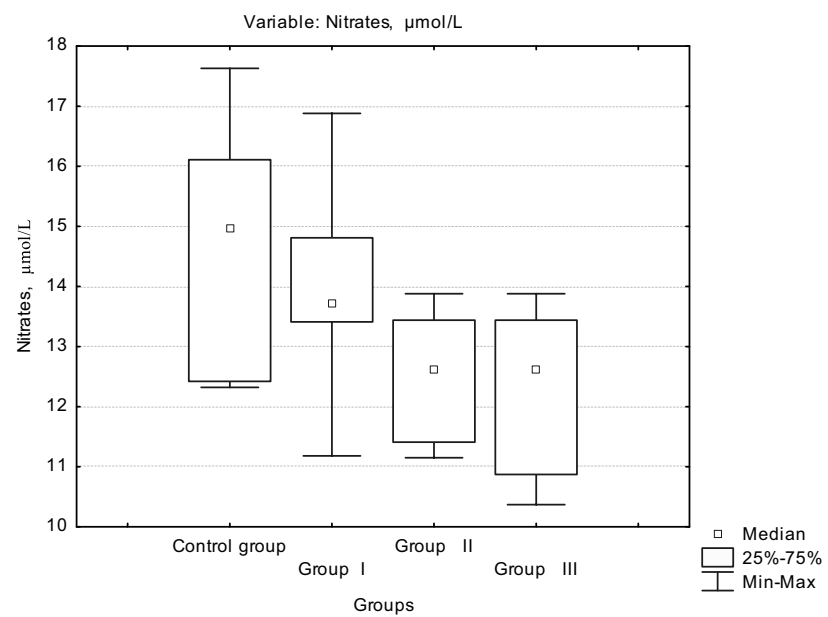

Figure 1. Salivary concentrations of nitrates in smokers and non-smokers.

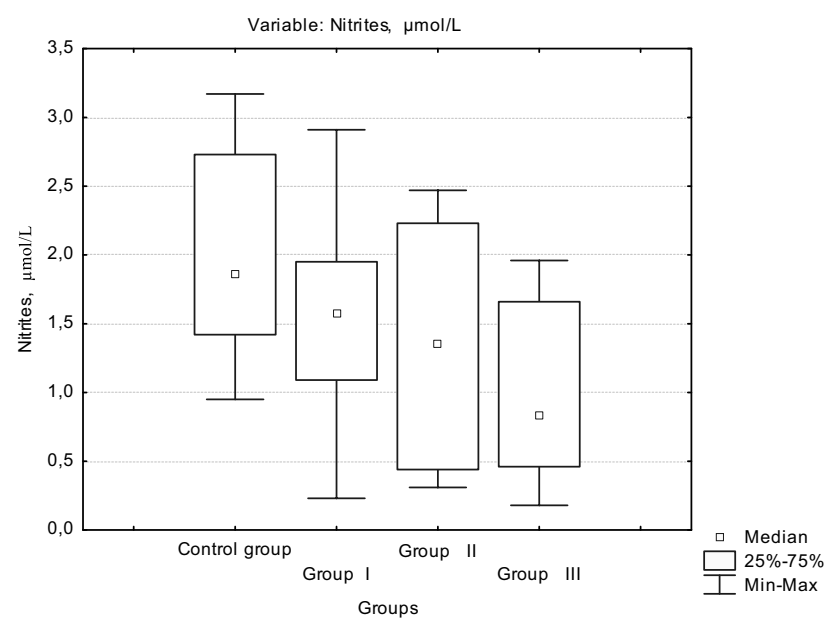

Figure 2. Salivary concentrations of nitrites in smokers and non-smokers.

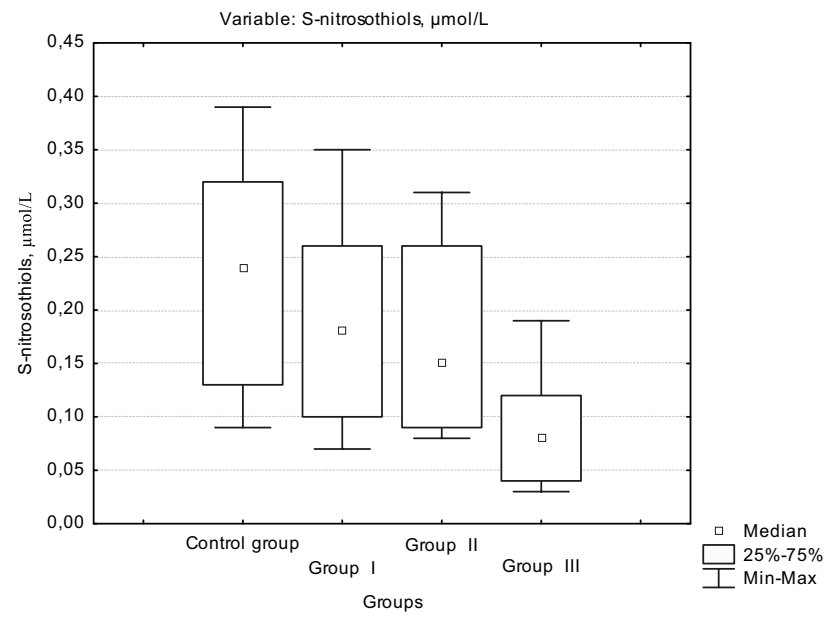

Figure 3. Salivary concentrations of S-nitrosothiols in smokers and non-smokers. correlation with number of daily cigarettes $(\mathrm{p}=0.0001)$. The number of cigarettes daily smoked by the subjects varied by duration of daily smoking: the increase of the duration of daily smoking led to elevate of the number of cigarettes smoked. Overall, systolic blood pressure and diastolic blood pressure did not differ between the control group and group I. However, the systolic blood pressure as well as diastolic blood pressure were significantly greater in group II and group III subjects as compared to controls. The mean body mass index (BMI) did not differ significantly among the groups. The salivary nitrate and nitrite levels in control group were measured $14.71 \pm 0.46$ $\mu \mathrm{mol} / \mathrm{L}$ and $2.05 \pm 0.19 \mu \mathrm{mol} / \mathrm{L}$, respectively.

The concentrations of salivary nitrate and nitrite in all groups of the smokers (group I, II and III) showed significant decrease compared to the control subjects. The concentrations for salivary nitrate and nitrite were for the group I $(13.92 \pm 0.37 \mu \mathrm{mol} / \mathrm{L}$ and $1.56 \pm 0.18 \mu \mathrm{mol} / \mathrm{L}$, respectively), group II $(12.50 \pm 0.24 \mu \mathrm{mol} / \mathrm{L}$ and $1.35 \pm 0.21$ $\mu \mathrm{mol} / \mathrm{L}$, respectively) and group III $(12.12 \pm 0.34 \mu \mathrm{mol} / \mathrm{L}$ and $1.06 \pm 0.16 \mu \mathrm{mol} / \mathrm{L}$, respectively). The values for the

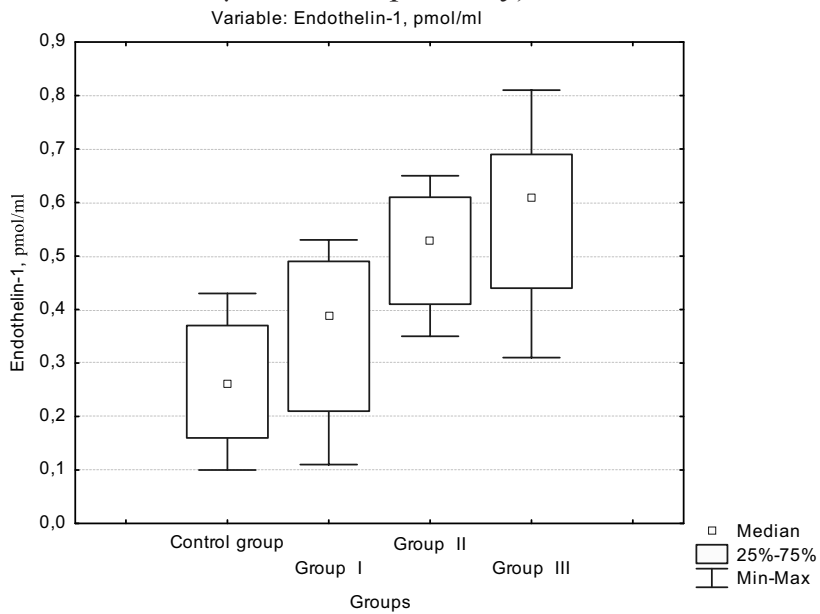

Figure 4. Salivary concentrations of endothelin-1in smokers and non-smokers.

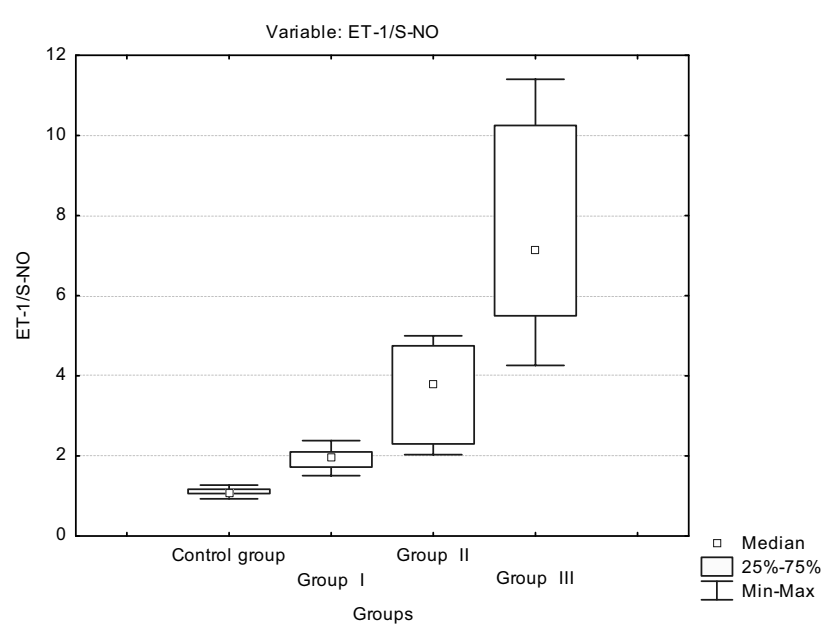

Figure 5. The endothelin-1/S-nitrosothiols ratio in smokers and non-smokers. 
control subjects were (salivary nitrates MW U test: ZC-I $=1.56 ; \mathrm{p}<0.119, \mathrm{ZC}$-II $=3.21 ; \mathrm{p}<0.001, \mathrm{ZCZC}$-III=3.30; $\mathrm{p}<0.001$; salivary nitrites $\mathrm{MW} \mathrm{U}$ test: $\mathrm{ZCZC}-\mathrm{I}=1.68$; $\mathrm{p}<0.093, \mathrm{ZC}_{\text {-II }}=2.24 ; \mathrm{p}<0.025, \mathrm{ZCZC}_{\text {-III }}=3.15 ; \mathrm{p}<0.016$ ) and (nitrates $\mathrm{KW}$ test: $\mathrm{H}=20.35 ; \mathrm{p}=0.000$; nitrites $\mathrm{KW}$ test: $H=11.28 ; p=0.010$ ) (Figure 1 and Figure 2).

Significantly reduction of salivary S-nitrosothiols values were observed in group II $0.17 \pm 0.02 \mu \mathrm{mol} / \mathrm{L}$ (MW $\mathrm{U}$ test: $\mathrm{ZC}$-II $=2.01 ; \mathrm{p}<0.044)$ and group III of smokers $0.09 \pm 0.01 \mu \mathrm{mol} / \mathrm{L}(Z C-$-III $=3.67 ; \mathrm{p}<0.000)$ compared to the values obtained in the control subjects $0.24 \pm 0.03 \mu \mathrm{mol} / \mathrm{L}$. The levels of salivary S-nitrosothiols in group I didn't show significant changes compared to the control subjects. Significant difference in salivary S-nitrosothiols levels was observed in group I and group III (KW test: $\mathrm{H}$ $=17.71 ; \mathrm{p}=0.000$ ) (Figure 3).

Concentration of endothelin-1 was significantly higher in group II $0.51 \pm 0.03 \mathrm{pmol} / \mathrm{mL}$ and in group III $0.58 \pm 0.04$ $\mathrm{pmol} / \mathrm{mL}$ compared to control group $0.26 \pm 0.03 \mathrm{pmol} / \mathrm{mL}$ and group I $0.35 \pm 0.04 \mathrm{pmol} / \mathrm{mL}(\mathrm{MW} U$ test: $\mathrm{ZC}-\mathrm{II}=-$ $4.293 ; \quad \mathrm{p}<0.000, \quad$ ZCZC-III $=-4.231 ; \quad \mathrm{p}<0.000, \quad \mathrm{ZI}-\mathrm{II}=-$ 2.779.50; $<<0.0054$, ZI-III $=-3.359 ; \mathrm{p}<0.000)$ and (KW test: $\mathrm{H}=30.38 ; \mathrm{p}=0.000)$. This difference was not observed between control group and group I (ZC-I =-1.804; $\mathrm{p}<0.071$ ) (Figure 4). It should be noted, the increase of endothelin-1 concentration was not significant in smokers of group I whom had a two-year period of cigarette consumption.

These results showed a possible correlation between increased salivary endothelin-1 level and duration of daily smoking and daily cigarette consumption in smokers of group II and group III. This can be considered a result of dysmetabolic vascular changes and an increase in the production of endothelin-1, since endothelin-1 is characterized by and intensification pro-oxidant effect and vasoconstrictor activity.

The endothelin-1/S-nitrosothiols ratio was calculated and the data was presented (Figure 5). Comparison the endothelin-1/S-nitrosothiols ratio was performed between groups of smokers and control group. There was the statistically significant difference between the comparing groups. ( $\mathrm{KW}$ test: $\mathrm{H}=53.09 ; \mathrm{p}=0.000$ ). There was a significant decrease in the salivary nitrates, nitrites, Snitrosothiols levels among the group II and group III of smokers with the lowest values seen in group III.

\section{DISCUSSION}

In order to assess the endothelium functions of vessels, we studied concentration of stable metabolites of nitric oxide and endothelin-1 levels in saliva of smokers and non-smokers. The results of the study demonstrated that the content of the vasoconstrictor factor, endothelin-1, was significantly increased by 1.96 - and 2.23 -fold in saliva samples of group II and group III, respectively, when compared to the non-smokers of control group. At the same time, the level of S-nitrosothiols which exhibits a vasodilator effect was significantly decreased by 1.4- and 2.7- fold in saliva samples of group II and group III, respectively, with regard to the control data.

The duration of smoking and the amount of daily cigarettes consumption resulted in a statistically notable elevation of salivary endothelin-1. However, the analysis of nitrates, nitrites and S-nitrosothiols in the same subjects of group II and group III probably as suppression of antioxidant system. Thus, the results demonstrated the presence of endothelial dysfunction in group II and group III. A similar though less pronounced dynamics of this parameter was in group I. Our results are consistent with other reports suggesting an association between smoking and endothelial dysfunction, and depletion of plasma antioxidants in the body $(16,20,21)$.

It has been known that endothelial dysfunction is characterized by an imbalance of the vasoconstriction and vasodilation factors, with a predominance of the vasoconstriction. The delicate balance between vasodilators and vasoconstrictors produced by the endothelium is disrupted, with disturbance in the NO pathway leading to predominance of vasoconstrictors like endothelin-1, which contribute to increase blood pressure in smokers of group II and group III (20). The present study indicates that the reduction of salivary nitrate, nitrite and S-nitrosothiols levels induced by cigarettes smoking correlated with duration of the cigarette consumption by young men of group II and group III. The prolonged cigarette consumption was associated with a decrease in the levels of stable metabolites of NO and these levels differed significantly between group I and group III of smokers.

The smoking is strong risk factor contributing toward atherogenesis and is associated with impaired endothelial function (16). The endothelium is important in maintaining vascular homeostasis and preventing the development of atherosclerosis. The perturbation of endothelium activity by cigarettes smoking led to endothelial dysfunction which increased with duration of smoking. Such endothelial dysfunction usually results in reduction of NO bioavailability (22).

The proatherogenic agents such as cigarette constituents give rise to increased free radical production (23). Salivary composition of cigarettes smokers is substantially altered with respect to free radical-involved mechanisms. Cigarette smoke contains free radicals and other oxidants in abundance. A single puff of a cigarette exposes the smoker to more than 1015 free radicals in the gas phase and additional radicals and oxidants in the tar phase (24). 
Many studies have reported on the relationship between cigarette smoking and BMI. Some studies have shown that active cigarette smoking is associated with high values of BMI $(25,26)$, although other studies have found the opposite and, according to these data, smokers have normal BMI even less compared with non-smokers $(27,28)$.

Our results indicated that the BMI values were normal in smokers and non-smokers. No differences were found in mean BMI among groups. Our finding of normal BMI among smokers, overall, is consistent with a number of other studies $(27,28)$. Possible explanation of the normal BMI in smokers is young age of smokers and short period of cigarette consumption. In addition, nicotine is known to increase the basal metabolic rate by up to $10 \%$ via sympathetic stimulated thermogenesis and oxidation of fatty acids (29). Nicotine can stimulate proopiomelanocortin system that lead to decrease of appetite in smokers (30).

The systolic blood pressure and diastolic blood pressure did not differ between the control group and group I. However, the systolic blood pressure as well as diastolic blood pressure were significantly higher in group II and group III subjects compared to controls. This could be explained as a result of increased vasoconstrictor effect of endothelin-1 in smokers of vasoconstrictor effect of increased endothelin-1 as consequence of smoking-related vascular changes. Endothelin-1 is linked to the pathogenesis of hypertension by means of low-grade vascular inflammation and oxidative stress at the vascular wall $(31,32)$. Our findings in terms of the endothelial dysfunction resulting from cigarette smoking impact are consistent with previous studies (33).

Therefore, results of this study show that cigarette smoking led to decreased stable metabolites nitric oxide (NO) and increased endothelin-1 in the salivary of smokers. The disruption of endothelium activity caused by cigarette smoking increased with duration of smoking.

We acknowledge some limitations to our study. This study was limited by age of young smokers who started smoking at age 14-18 years, so maximum duration of cigarette smoking was six years.

\section{CONFLICT OF INTEREST}

The authors declare that there is no conflict of interest regarding the publication of this paper.

\section{LIST OF ABBREVIATIONS}

$\mathrm{BP}$ - blood pressure

BMI - body mass index

SEM - standard error of mean
KW - Kruskal-Wallis test

MW U test - Mann-Whitney U test

CVD - cardiovascular diseases

ROS - reactive oxygen species

\section{REFERENCES}

1. Bernhard D, ed. Cigarette smoke toxicity: linking individual chemicals to human diseases. 1st ed. Weinheim: Wiley-VCH Verlag GmbH \& Co. KGaA; 2011.

2. Kumar M, Nanavati R, Modi TG, Dobariya C. Oral cancer: etiology and risk factors: a review. J Cancer Res Ther 2016;12:458-63.

3. Global adult tobacco survey. Ukraine 2017. Executive Summary. Ministry of Health of Ukraine, Kiev International Institute of Sociology, World Health Organization Regional Office for Europe, National Academy of Medical Sciences of Ukraine, U.S. Centers for Disease Control and Prevention. (www.euro.who.int/en/countries/ukraine/ publications/ global- adult-tobacco-survey-ukraine-2017).

4. Messner B, Bernhard D. Smoking and cardiovascular disease: mechanisms of endothelial dysfunction and early atherogenesis. Arterioscler Thromb Vasc Biol 2014;34:509-15.

5. Salahuddin S, Prabhakaran D, Roy A. Pathophysiological mechanisms of tobacco-related CVD. Glob Heart 2012;7:113-20.

6. Widmer RJ, Lerman A. Endothelial dysfunction and cardiovascular disease. Glob Cardiol Sci Pract 2014;2014:291-308.

7. Ozaki K, Hori T, Ishibashi T, Nishio M, Aizawa Y. Effects of chronic cigarette smoking on endothelial function in young men. J Cardiol 2010;56:307-13.

8. Ichiki T. Collaboration between smokers and tobacco in endothelial dysfunction. Cardiovasc Res 2011;90:395-6.

9. Sandoo A, van Zanten JJ, Metsios GS, Carroll D, Kitas GD. The endothelium and its role in regulating vascular tone. Open Cardiovasc Med J 2010;4:302-12.

10. Barton M, Baretella O, Meyer MR. Obesity and risk of vascular disease: importance of endotheliumdependent vasoconstriction. $\mathrm{Br} \mathrm{J}$ Pharmacol 2012;165:591-602.

11. Gimbrone MA, García-Cardeña G. Endothelial cell dysfunction and the pathobiology of atherosclerosis. Circ Res 2016;118:620-36.

12. Kamceva G, Arsova-Sarafinovska Z, Ruskovska T, Zdravkovska M, Kamceva-Panova L, Stikova E. Cigarette smoking and oxidative stress in patients with coronary artery disease. Maced J Med Sci 2016;4:636-40. 
13. Alinde OBL, Esterhuyse AJ, Oguntibeju OO. Role of reactive oxygen species in the pathogenesis of cardiovascular disease. Sci Res Essays 2012;7:4151-9.

14. Panth N, Paudel KR, Parajuli K. Reactive oxygen species: a key hallmark of cardiovascular disease. Adv Med 2016; 2016:9152732.

15. Berzigotti A, Erice E, Gilabert R, et al. Cardiovascular risk factors and systemic endothelial function in patients with cirrhosis. Am J Gastroenterol 2013;108:75-82.

16. Rigotti NA, Clair C. Managing tobacco use: the neglected cardiovascular disease risk factor. Eur Heart J 2013;34:3259-67.

17. Toda N, Okamura T. Cigarette smoking impairs nitric oxide-mediated cerebral blood flow increase: implications for Alzheimer's disease. J Pharmacol Sci 2016;131:223-32.

18. Henson BS, Wong DT. Collection, storage, and processing of saliva samples for downstream molecular applications. Methods Mol Biol 2010; 666:21-30.

19. Miranda KM, Espey MG, Wink DA. A rapid, simple spectrophotometric method for simultaneous detection of nitrate and nitrite. Nitric Oxide 2001;5:62-71.

20. Fratta Pasini A, Albiero A, Stranieri C, et al. Serum oxidative stress-induced repression of Nrf2 and GSH depletion: a mechanism potentially involved in endothelial dysfunction of young smokers. PLoS One 2012;7:e30291.

21. Paracha P, Khan T, Vriesekoop F, et al. Association between smoking and anthropometric characteristics, biochemical markers, and dietary intake of Pakistani male adult population. Adv Food Technol Nutr Sci Open J 2015;1:88-96.

22. Ramzy D, Rao V, Tumiati LC, et al. Elevated endothelin-1 levels impair nitric oxide homeostasis through a PKC-dependent pathway. Circulation 2006;114:I319-26.

23. Phaniendra A, Jestadi DB, Periyasamy L. Free radicals: properties, sources, targets, and their implication in various diseases. Indian J Clin Biochem 2015;30:11-26.
24. Pham-Huy LA, He H, Pham-Huy C. Free radicals, antioxidants in disease and health. Int J Biomed Sci 2008;4:89-96.

25. Slagter SN, van Vliet-Ostaptchouk JV, Vonk JM, et al. Associations between smoking, components of metabolic syndrome and lipoprotein particle size. BMC Med 2013;11:195.

26. Morris RW, Taylor AE, Fluharty ME, et al. Heavier smoking may lead to a relative increase in waist circumference: evidence for a causal relationship from a Mendelian randomisation meta-analysis. The CARTA consortium. BMJ Open 2015;5:e008808.

27. Audrain-McGovern J, Benowitz NL. Cigarette smoking, nicotine, and body weight. Clin Pharmacol Ther 2011;90:164-8.

28. Freathy RM, Kazeem GR, Morris RW, et al. Genetic variation at CHRNA5-CHRNA3-CHRNB4 interacts with smoking status to influence body mass index. Int J Epidemiol 2011;40:1617-28.

29. Martínez de Morentin PB, Whittle AJ, Fernø J, et al. Nicotine induces negative energy balance through hypothalamic AMP-activated protein kinase. Diabetes 2012;61:807-17.

30. Mineur YS, Abizaid A, Rao Y, et al. Nicotine decreases food intake through activation of POMC neurons. Science 2011;332:1330-2.

31. Piechota A, Polańczyk A, Goraca A. Role of endothelin-1 receptor blockers on hemodynamic parameters and oxidative stress. Pharmacol Rep 2010;62:28-34.

32. Grebla RC, Rodriguez CJ, Borrell LN, Pickering TG. Prevalence and determinants of isolated systolic hypertension among young adults: the 1999-2004 US National Health and Nutrition Examination Survey. J Hypertens 2010;28:15-23.

33. Amiya E, Watanabe M, Komuro I. The relationship between vascular function and the autonomic nervous system. Ann Vasc Dis 2014;7:109-19. 